Olena Oliynyk

Liudmyla Oliinyk

Victor Adamenko

\title{
1.7. AGRICULTURAL FINANCIAL SYSTEM IN UKRAINE
}

\begin{abstract}
Summary
The agricultural sector of Ukraine has significant financial needs. According to different experts' estimates there is agrifinance gap of USD 8.7 billion in the Ukraine. In this paper we will evaluate major financial intermediaries for agriculture in Ukraine. In particular, we will characterize the main financial institutions which supply the financial services to the agricultural sector; we will get an understanding of the underlying reasons of limited funding for agriculture. As well we will explore various performance criteria which determine the effectiveness of financial intermediation for agriculture such as efficient allocation of loan funds, interest rates on agricultural loans.
\end{abstract}

Keywords: agriculture, financial institutions, evaluation, financial intermediation

\section{Introduction}

Agriculture plays an important role in economy of Ukraine and has the potential to be a source of growth in a future. Ukraine is considered as one of the countries with the richest natural agricultural factor endowments with long-term investment opportunities (Global Ag Investments, LLC 2013). The share of agriculture in gross domestic product of Ukraine is about $20 \%$. The sector represents more than $20 \%$ of the country's export. However, it accounted for only 5,9\% loans in 2011.

According the assessments of experts' access to finance is a major constraint of the productivity and growth of agribusiness players (OECD, 2012a). Despite accounting for about $20 \%$ of the country's GDP, agriculture does not receive enough loans to finance working capital and investment. The banks in Ukraine are reluctant to lend to farms and hedge themselves against risk by raising either the interest rate on loans or collateral requirements. As well, insufficient understanding of agricultural production leads banks to increase their interest rates to cover for risks they cannot properly assess.

Financing the agriculture through the budget system in Ukraine has increased sharply over the last 10 years, but this did not lead to increasing the efficiency and the competitiveness of agriculture (Oliynyk, 2012a).

Different farm organizational structures and farm sizes might affect also different financial systems, which are applied in agriculture. Therefore, we analyze features of agriculture in Ukraine in terms of their farm organizational structures, their farm size structures and evolution in association with development of an efficient financial system for multifunctional roles of agriculture and for rural development. 


\section{Material and methods}

The financial system is often defined in the literature in a narrow sense, i.e., as a set of financial institutions - markets and intermediaries - through which households, corporations and government obtain funding for their activities and invest their savings (Bodie and Merton 2000; Allen and Gale 2001; Hartmann et al. 2003). Some other (e.g., Schmidt and Hackethal 2006; Hryckiewicz, Schmidt and Tyrell 2001, 2003) argue that the conceptual starting points are financial decisions and activities of nonfinancial firms and households. From their point of view the concept of the financial system is a broader than previous definition. Within the financial system, they are considering financial relationships of households and firms that occur through the financial sector and outside the financial sector. Examples are real savings, selffinancing and self-insurance, and informal and direct lending and borrowing relationships. Financial relations of the state with other economic agents concerning to the flow of financial instruments on non-repayable and non-equivalent fiscal relations have not been considered in the concept of the financial system of a given country or region.

The analysis of literature shows that the concept of the financial system is complex and multifaceted. Definition of the term "financial system" is often missing in fundamental works devoted to the study of the theory and practice of financial systems (Bain 1996; Buckle and Thompson 1998).

Based on the definition of "system" as a set of any items, pieces, parts, joined by a common feature, the purpose, we can determine that a common feature of the elements of the financial system is that they provide flow of financial instruments. Under the elements of the financial system should be understood entities of the financial system that have been identified according to harmonization institutional sectors: government, non-financial corporations, financial corporations, households, and non-profit organizations. If we would like to consider the concept of the financial system comprehensively, we should include to the financial system the financial relations of the state with other economic agents concerning to flow of financial instruments on a non-repayable and non-equivalent basis. Therefore, the financial system is the sum of economic entities, which comes together in financial relations according to the flow of financial instruments on the equivalent and non-equivalent basis.

Our aim is to analyze the agricultural financial system in Ukraine. We aim to analyze the ways in which financial relationships of farms with other economic agents through the financial sector as well as without financial sector on the equivalent and non-equivalent basis are designed and implemented. The paper contributes to the analyses on the ways in which farms meet their financial needs through the financial sector, directly with other economic agents and through the budgetary system.

Evaluation of the financial relationships agriculture with budget system is assessed on the basis of the OECD indicators which are available for Ukraine. One of the most known is the Producer Support Estimate (PSE).

The previous studies of investment behaviour for a sample of Ukrainian large farms 2001-2005 provided empirical evidence for the coexistence of financial constraints and soft budget constraints (Zinych and Odening 2009). Credit constraints are more 
important than soft budget constraints. Large farms' investments significantly depend on financial variables in an imperfect capital market in Ukrainian agriculture. The presence of soft budget constraints was identified also for investment behaviour of a sub-sample of large non-private Ukrainian firms (Mykhayliv and Zauner 2013a, 2013b). Distortions to incentives in Ukrainian agriculture, including for capital market, have been widely analysed in the literature (von Cramon-Taubadel et al. 2001, 2007).

\section{Results and discussion}

\section{Farm structures and the role of agriculture in the economy}

Ukraine's farm sector is characterized by a three-way split between tiny household farms, medium-sized private farms and large corporate farms. State-owned agricultural enterprises are not significant players.

Table 1: Agricultural land use by categories of farms in Ukraine

\begin{tabular}{|c|c|c|c|c|c|c|c|c|}
\hline \multirow{2}{*}{$\begin{array}{l}\text { The legal } \\
\text { type of } \\
\text { farms }\end{array}$} & \multicolumn{4}{|c|}{2006} & \multicolumn{4}{|c|}{2012} \\
\hline & $\begin{array}{c}\text { Number of } \\
\text { units }\end{array}$ & $\begin{array}{l}\text { '000 } \\
\text { ha }\end{array}$ & $\%$ & $\begin{array}{l}\text { Average } \\
\text { size (ha) }\end{array}$ & $\begin{array}{c}\text { Number of } \\
\text { units }\end{array}$ & $\begin{array}{l}\text { '000 } \\
\text { ha }\end{array}$ & $\%$ & $\begin{array}{l}\text { Average } \\
\text { size (ha) }\end{array}$ \\
\hline $\begin{array}{l}\text { Rural } \\
\text { households* }\end{array}$ & $15.1 * *$ & 15602 & 37.4 & 1.0 & $14.3 * *$ & 15815 & 38.1 & 1.1 \\
\hline $\begin{array}{l}\text { Private } \\
\text { farms*** }\end{array}$ & 42932 & 3972 & 9.5 & 93 & 40732 & 4389 & 10.6 & 108 \\
\hline $\begin{array}{l}\text { Private } \\
\text { agricultural } \\
\text { entities }\end{array}$ & 13030 & 16051 & 38.5 & 1232 & 13160 & 15313 & 36.9 & 1164 \\
\hline $\begin{array}{l}\text { State-owned } \\
\text { agricultural } \\
\text { enterprises }\end{array}$ & 371 & 1177 & 2.8 & 3173 & 294 & 963 & 2.3 & 3276 \\
\hline $\begin{array}{l}\text { Enterprises } \\
\text { of other } \\
\text { types of } \\
\text { business }\end{array}$ & 1525 & 4874 & 11.7 & 3196 & 1680 & 5056 & 12.2 & 3010 \\
\hline Total & $57858 * * * *$ & 41676 & 100 & - & $55866 * * * *$ & 41536 & 100 & - \\
\hline
\end{tabular}

* Rural households, which own or use the land and their residence is registered in rural settlements.

** The number of rural population (in million).

*** Private farm is a form of private business of citizens with legal person's right, who has expressed the wish to produce commodity production, to process and sell it with purpose to gain a profit. Citizens carry out their activity on land plots, which were placed at their disposal for farming.

**** the amount is without "Rural households"

Source: SSSU (2007, 2012a, 2012b, 2013). 
In the agricultural land use structures, there are mostly legal entities in Ukraine (Table 1). Their share in total agricultural land use was more 60\%. However, rural households (family farms) have important role in agriculture in Ukraine. The share of this type of farms indicates their substantial importance in the Ukrainian agricultural land use structure, and increased from $37.4 \%$ in 2006 to $38.1 \%$ in 2012 . They can be also important for cash-flows into rural households' farms by sell of surpluses of agricultural products such as potatoes, fruit, vegetables and milk at local free-markets.

Rural households play key role in agricultural production in Ukraine (see table 2). Although the share of rural households in agricultural output decreased by $12.8 \%$, it remains significant and consists $49.3 \%$ in 2012. Private agricultural entities play major role in agricultural output as well. Increasing the percentages of private agricultural entities in agricultural production from $33.3 \%$ in 2006 to $49.7 \%$ in 2012 was caused the emergence and development of large agricultural enterprises. On average, they have relatively high capacity due to a vertically integrated structure and implementation of new technologies. As mentioned above, the state agricultural enterprises are minor players and they generated merely about 1.0 per cent of the country's gross agricultural output in 2012 .

Table 2: Gross agricultural production, by main groups of producers

\begin{tabular}{|l|c|c|c|r|}
\hline \multirow{2}{*}{ The legal type of farms } & \multicolumn{2}{c|}{2006} & \multicolumn{2}{c|}{2012} \\
\cline { 2 - 5 } & mIn. UAH & $\begin{array}{c}\text { percentage } \\
\text { to total }\end{array}$ & mIn. UAH & \\
\hline Rural households & 57886.4 & 61.0 & 110172.5 & 49.3 \\
\hline Private farms & 4097.0 & 4.3 & 14111.1 & 6.3 \\
\hline Private agricultural entities & 31594.1 & 33.3 & 110905.5 & 49.7 \\
\hline State agricultural enterprises & 1317.1 & 1.4 & 2176.8 & 1.0 \\
\hline Total & 94894.6 & 100.0 & 223254.8 & 100.0 \\
\hline
\end{tabular}

Source: $\operatorname{SSSU}(2007,2013)$.

As can be seen from Figure 1, the average size of agricultural enterprises has increased between 2006 and 2012. The percentage of agricultural enterprises greater than 10000 ha of agricultural land use has also increased from 3.3\% in 2006 to $15.3 \%$ in 2012. There are the four main factors, which influence on rapid increase of big agricultural enterprises. Firstly, the private enterprises in the agricultural sector were formed, which allowed to merge these forms in the holdings. Secondly, at that time influential and in lobbying powerful capital owners emerged in Ukraine, who aimed to multiply their capital in the long-term perspective. A certain number of large capital owners were from the food industry. They were interested in the vertical integration of agricultural producers to minimize costs. Thirdly, the lack of appropriate institutional and legal conditions for the fully-fledged agricultural land market leads to the opportunity to develop lease market and to lease land for low costs and, consequently, making the agricultural land of unlimited production resources (Oliynyk 2011a). In 
addition, among the reasons for their rapid increase are migration of labour from rural areas and greater availability of land with opportunities for further large agricultural enterprise concentration. Finally, in privatisation of some agricultural enterprises has been engaged also foreign capital through stock exchange markets (Balmann et al. 2013). Stock exchange markets are one of opportunities for access of capital, which is needed for investments and technological advancements of large commercial agricultural enterprises.

Figure 1: Distribution of agricultural enterprises in operation by the size of agricultural land use in Ukraine

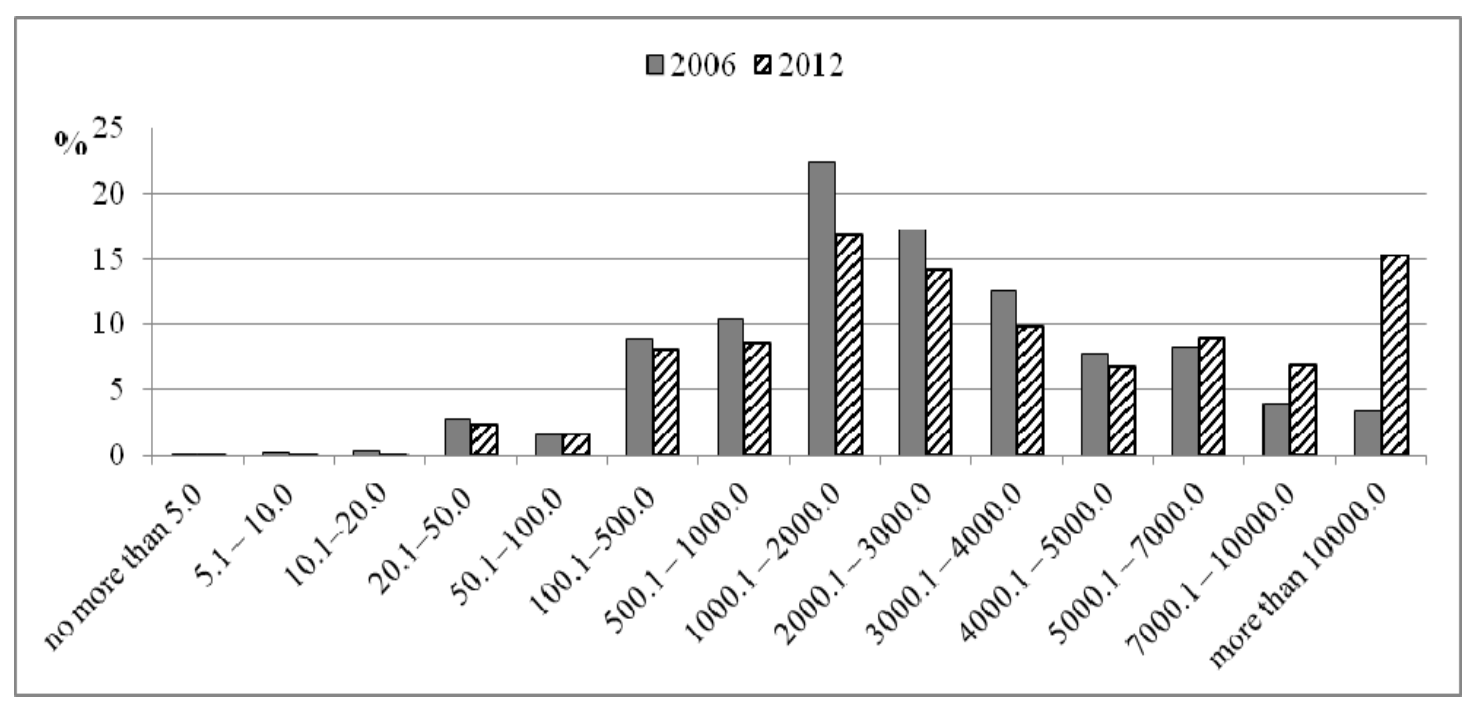

Source: SSSU (2007, 2013).

As can be seen from Table 3, the percentage of employment in agriculture in the Ukrainian economy decreased slightly from $17.5 \%$ in 2006 to $17.2 \%$ in 2012 . This declined has been caused by the increasing role of the large agricultural enterprises (agroholdings of the average size more than 50000 ha), which have implemented new advanced technologies on a large-scale farms. Consequently, these large-scale agricultural enterprises in Ukraine have shed the labour, which has also migrated out of the rural areas and to abroad. On the other hand, the share of value added of agriculture, forestry and hunting in the gross domestic product of the Ukrainian economy increased from $8.6 \%$ in 2006 to $9.2 \%$ in 2012 .

Table 3: The role of agriculture, forestry and fishing in the economy of Ukraine

\begin{tabular}{|l|r|r|r|r|r|r|r|}
\hline & $\mathbf{2 0 0 6}$ & $\mathbf{2 0 0 7}$ & $\mathbf{2 0 0 8}$ & $\mathbf{2 0 0 9}$ & $\mathbf{2 0 1 0}$ & $\mathbf{2 0 1 1}$ & $\mathbf{2 0 1 2}$ \\
\hline $\begin{array}{l}\text { Value added of agriculture in } \\
\text { gross domestic product (\%) }\end{array}$ & 8.6 & 7.5 & 7.9 & 8.3 & 8.7 & 9.9 & 9.2 \\
\hline $\begin{array}{l}\text { Employment in agriculture in } \\
\text { the economy (\%) }\end{array}$ & 17.5 & 16.6 & 15.7 & 15.5 & 15.3 & 16.7 & 17.2 \\
\hline
\end{tabular}

Source: SSSU (2012b, 2013) 
Dibrova, A. - Kukhar, O.

\section{The role of the financial sector in the financing of agriculture in Ukraine}

The financial system is understood how farms meet their financial needs through the financial sector, directly with other economic agents and through the budgetary system. Thus, we analyse the main suppliers of agricultural finance.

Except for rural households, Ukrainian farms satisfy their need for finance mainly through commercial banks. Other financial institutions such as credit unions, leasing companies, insurance companies and other financial markets play marginal role in funding of farms in Ukraine (Oliynyk and Oliinyk, 2013).

According to the data presented in Figure 2, during the years 2000 - 2012 there was a positive tendency in the value of loans in constant prices for lending to agriculture by commercial banks. The value of loans at constant prices increased by 46 times and it was 31.9 billion UAH in 2012. The main reasons for the increase in the value of loans have been the introduction of the interest rate subsidy programme since 2000, the emergence and development of large enterprises, which have experienced relatively high profitability.

On the other hand, the share of agriculture, hunting and forestry in total loan portfolio of banks has fluctuated during the years $2000-2012$ between $3.7 \%$ in 2000 and $7.8 \%$ in 2003. The highest share of agriculture, hunting and forestry in the structure of the bank loans in 2003 can be explained by significant increasing in the government support to agriculture through the interest rate subsidy programme from 120 million UAH in 2002 to 326 million UAH in 2003. Since 2003, this share has tended to decline, particularly by the most recent economic and financial crisis.

Figure 2: The loan portfolio of commercial banks to agriculture, hunting and forestry in Ukraine, in constant prices of the year 2000*

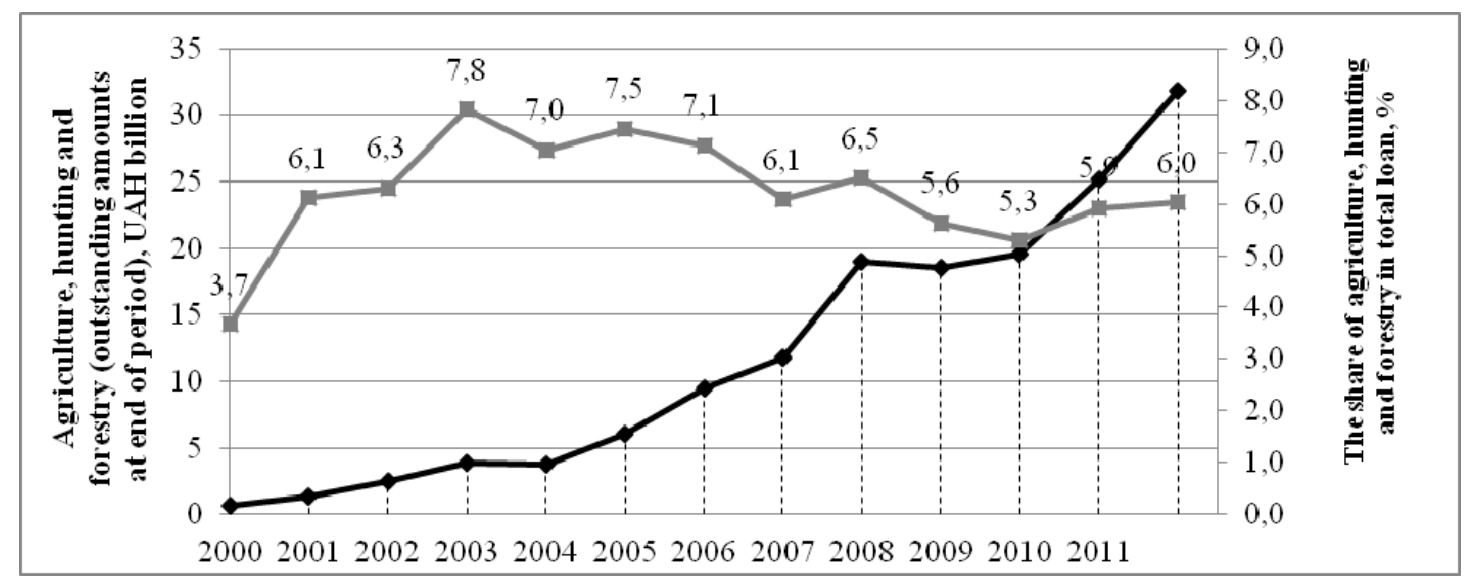

*Loans deflated using price indices for industrial production $(2000=$ base period $)$

Source: National Bank of Ukraine $(2012,2013)$

The interest rate subsidy programme played an important role in financing agricultural enterprises, especially in 2005 and 2008 (see Figure 3). Thus, during 20052008 the share of preferential loans in total loans was over $50 \%$ and reached more than $70 \%$ in 2005 and 2008. The high share of preferential loans in the portfolio shows that the high interest rate is the main factor that restricts access the agricultural enterprises 
to loans. The financial crisis affected significantly the preferential loans because the funding from the budget decreased sharply. As a result the share of preferential loans was only $9.0 \%$ in 2012 .

Figure 3: The amount of bank loans granted to agricultural enterprises, including preferential loans, UAH million

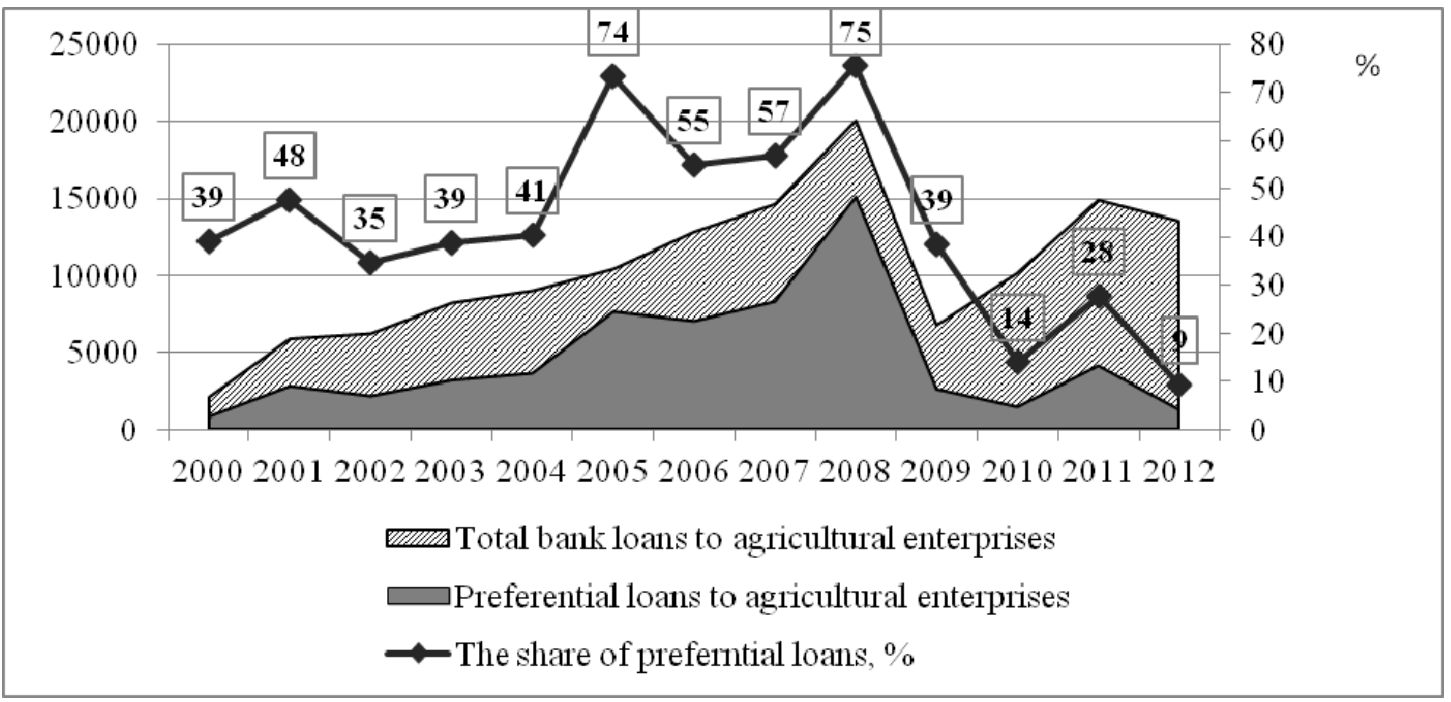

Source: Ministry of Agriculture Policy and Food of Ukraine (2001-2012)

Despite significant impact of interest subsidy scheme on agriculture lending, it has been argued that these schemes actually create market distortions, since support is not allocated through a market-based mechanism but rather through direct state subsidies. Furthermore, these measures do not target small and medium enterprises (SMEs) and have very broad eligibility criteria for the right to use the program, which means that the actual beneficiaries are mainly large market participants (von Cramon-Taubadel et al., 2007). Similar findings by experts from USAID and OECD, indicating that the program covered a small number of farms, and the farms benefitting from the scheme are not necessarily credit constrained (OECD, 2012b). Generally note the following shortcomings of interest subsidy program (OECD, 2012b). First, eligibility criteria for the programme are not defined: all businesses can apply, irrespective of their size, turnover and the purpose of the loan. Second, subsidies have no size limit relative to the size of the loan. Therefore, market participants who received a large loan, receive large subsidies and thus it includes fewer companies. Thirdly, the application process is complex and lacks transparency. Fourth, banks have an incentive to raise interest rates for agriculture, when they know that the borrower will receive a subsidy from the support scheme.

The agriculture is generally not the first priority of many commercial banks in Ukraine. Some banks are working with agricultural enterprises, but they clearly differentiate between companies according to size. Larger vertically integrated agriholdings are attractive clients for commercial banks as well as for international financial institutions such as the IFC, EBRD and others. Smaller farms and rural households are underrepresented in bank portfolios (EFSE, 2012). 
Despite the large number of commercial banks in Ukraine (175 at the end of 2011), half of loans to agriculture are concentrated in the 10 commercial banks (Table 4). The largest share of the market belongs to two powerful banks in Ukraine - PrivatBank and UkrEximBank. Together, they hold more than 23 per cent of the total agricultural portfolio. Their clients are predominantly large enterprises. These two banks are offering wide range of products and services, but they do not have specialized products for agriculture.

Table 4: Top 10 banks serving the agriculture, hunting and forestry (as outstanding amounts at end of 2011), UAH billion

\begin{tabular}{|l|c|c|c|}
\hline \multicolumn{1}{|c|}{ Bank } & $\begin{array}{c}\text { Total loan } \\
\text { portfolio }\end{array}$ & $\begin{array}{c}\text { Loans to agriculture, } \\
\text { hunting and forestry }\end{array}$ & $\begin{array}{c}\text { The share agriculture, } \\
\text { hunting and forestry } \\
\text { in bank sector, \% }\end{array}$ \\
\hline PrivatBank & 113,5 & 3,4 & 10,0 \\
\hline UkrEximBank & 42,9 & 4,4 & 12,9 \\
\hline Financial Initiative & 9,7 & 2,8 & 8,2 \\
\hline Raiffeisen Bank Aval & 30,3 & 2,4 & 7,0 \\
\hline Oschadbank & 58,8 & 1 & 2,9 \\
\hline PromInvest Bank & 29,2 & 1 & 2,9 \\
\hline Sberbank of Russia & 15,4 & 0,6 & 1,8 \\
\hline First Ukrainian & 2,1 & 0,4 & 1,2 \\
\hline International Bank & 11,3 & 0,3 & 0,9 \\
\hline Bank Forum & 3,1 & 0,2 & 0,6 \\
\hline Credit Agricole Bank & 316,3 & 16,5 & 48,4 \\
\hline Total 10 banks & 259,2 & 17,6 & 51,6 \\
\hline Other banks & 575,5 & 34,1 & 100,0 \\
\hline Total banks & & & \\
\hline
\end{tabular}

Source: annual reports of the commercial banks, 2011; National Bank of Ukraine (2012)

Certain market share of agricultural lending composes the banks, which is the affiliates of international financial groups. These include Raiffeisen Bank Aval (Raiffeisen Banking Group, Austria), Bank Forum (Commerzbank, Germany), Credit Agricole Bank (Credit Agricole Group, France) and others. Experience the mother companies allows these banks to develop specialized loan products for agriculture.

Compare the loans to agriculture with GDP in agriculture indicated (Figure 4) positive tendency, every year debt capacity of agriculture (calculated as the ratio the agricultural loans to GDP in agriculture) increases from $0,7 \%$ in 2001 to $15,8 \%$ in 2012. Regression analysis shows the significant relation between loans and GDP in agriculture (Figure 5). The determination coefficient is 0,79 . However, on the other hand tendency of the reverse index to indicator debt (Figure 6) shows that the effectiveness of loans decreased significantly. This is evidence about the use of loan deterioration, but not about the efficiency of the agricultural financial system as a whole. 
Figure 4: Debt capacity of agriculture and GDP in agriculture in Ukraine

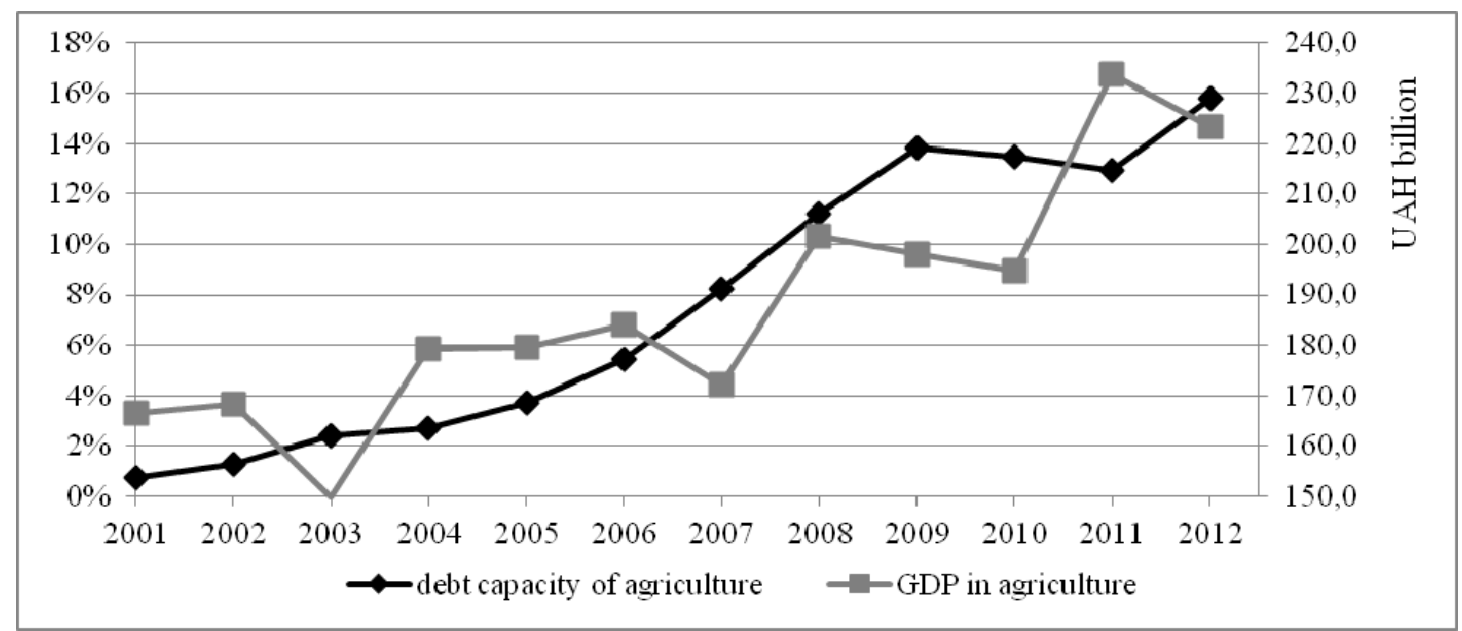

Source: SSSU (2012b, 2013), National Bank of Ukraine (2012, 2013)

Figure 5: Relation between loans and GDP in agriculture

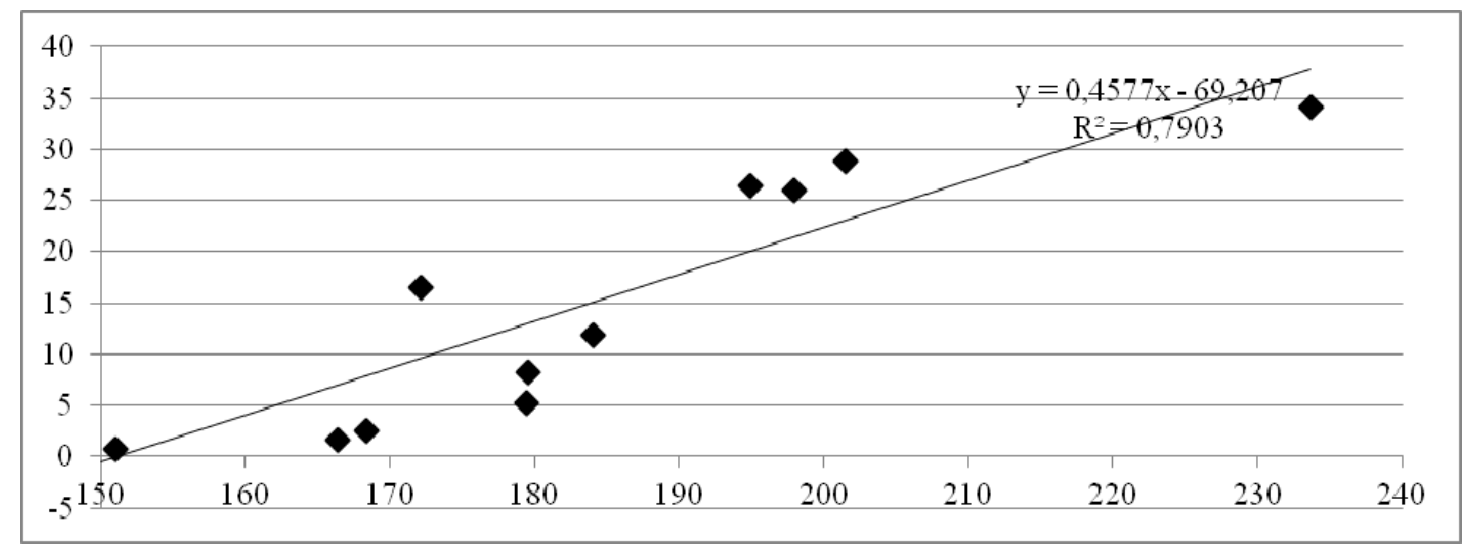

Source: SSSU (2012b, 2013), National Bank of Ukraine (2012, 2013)

Figure 6: The effectiveness of loans (the ratio GDP in agriculture to agricultural loans)

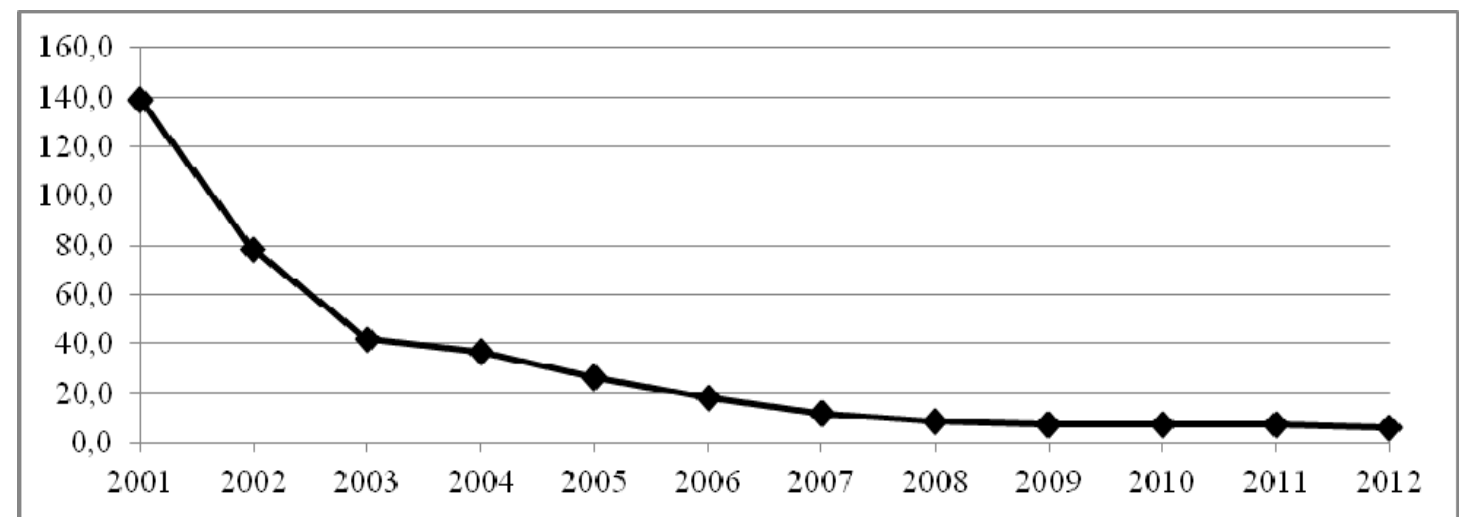

Source: SSSU (2012b, 2013), National Bank of Ukraine (2012, 2013) 
In a spite of the increasing value of loans to agriculture in both current and constant prices, the agro-finance supply of about UAH 36 billion failed to meet short-term demands by agricultural farms, which is estimated at UAH 96 billion (EFSE 2012). The main obstacles of agricultural lending development in Ukraine are on the supplyside, on the commercial banks, which are facing the lack of specialized risk assessment tools to be used in evaluating business strategies and loan applications of farms. Most of commercial banks due to the lack of understanding of the specificities of agricultural production and the inability to assess adequately the risks associated with farming activities and farmers, they resort to higher interest rates, which in turn lead to a reduction in the demand-side for loans by farms. On the demand-side, about $35 \%$ of all Ukrainian farms are trapped in a vicious circle of low solvency, low yields, low margins, poor management and bad economic performance with low creditworthiness (EFSE 2012).

Despite the huge natural agricultural factor endowments potentials of Ukrainian agriculture, commercial banks are currently with their loans supply focusing only on the largest agribusiness players. According to the assessments by the Organisation for Economic Cooperation and Development (OECD 2012a), the European Bank for Reconstruction and Development and the World Bank (EBRD-World Bank 2009), access to finance is a major obstacle and constraint of agricultural productivity and growth of agribusiness players in Ukraine. This is particularly relevant obstacle for small and medium enterprises (Bojnec, Kvasha and Oliynyk 2013).

The credit unions are small players in the credit market. They have small proportion in-service agribusiness. Credit unions suffered from financial crisis more than the banking sector as it did not receive any support from the National Bank of Ukraine or the Government. Credit unions had to rely on members to support their liquidity. The situation is complicated by the fact that in Ukraine there is no common institution for refinancing credit unions and commercial banks were reluctant to lend to them. As a result, the number of credit unions has declined from 829 in 2008 to 613 in 2011. The volume of loans to member credit unions has declined by almost $60 \%$ (from $5.6 \mathrm{UAH}$ billion in 2008 to $2.2 \mathrm{UAH}$ billion in 2011). The share of loans to individuals and private farms in the loan portfolio of credit unions was $6 \%$ in 2011 , which amounted to 44.7 million UAH, which is only $0.3 \%$ of the bank loans to agriculture in 2011 .

The development of credit unions is limited by a series of constraints. They are allowed to lend only to individuals and only in local currency. A further essential constraint is the absence of a functioning refinancing organization balancing the liquidity needs of credit unions. Also there is no effective mechanism to protect the rights of members of credit unions, including the deposit insurance system, poor control of credit unions and the lack of financial help by state, low level professional and technical equipment of the vast majority of credit unions that generates imperfect structure loan portfolio, policy development and management of assets and liabilities, the lack of implementation of new services and market instruments, the lack of a coherent long-term market strategy and more.

Leasing companies are the following supplier loans for agriculture. The leasing business in Ukraine consist a small portion of total investments in the economy. At the 
end of 2012, 243 leasing companies and 115 financial companies had lease agreements in agriculture, with a total value of 7.9 UAH billion (see Figure 7).

The leasing agreements in agriculture is rapidly increasing from 2007 to 2012 in five times (see Figure 7) in despite of the financial crisis. The first reason for the growth in leasing is following. In recent years, commercial banks have understood the advantages of leasing over conventional lending and have started to actively engage in such activities, typically through daughter companies. The leasing companies can increase their portfolios rapidly whereas the banks are limited by strict reserve requirements. The next reasons for the growth in leasing are the improved tax environment and the overall economic recovery and, in particular, agriculture. The profitability level of agricultural enterprises has increased from $7.7 \%$ in 2008 to $16.2 \%$ in 2012.

The share of agriculture in lease transactions has been growing strongly over the last five years, from 8\% in 2007 to $19 \%$ in 2012 (see Figure 7). Agriculture was the second most important sector after transport.

Figure 7: Volume of leasing operation in agriculture, 2007-2012

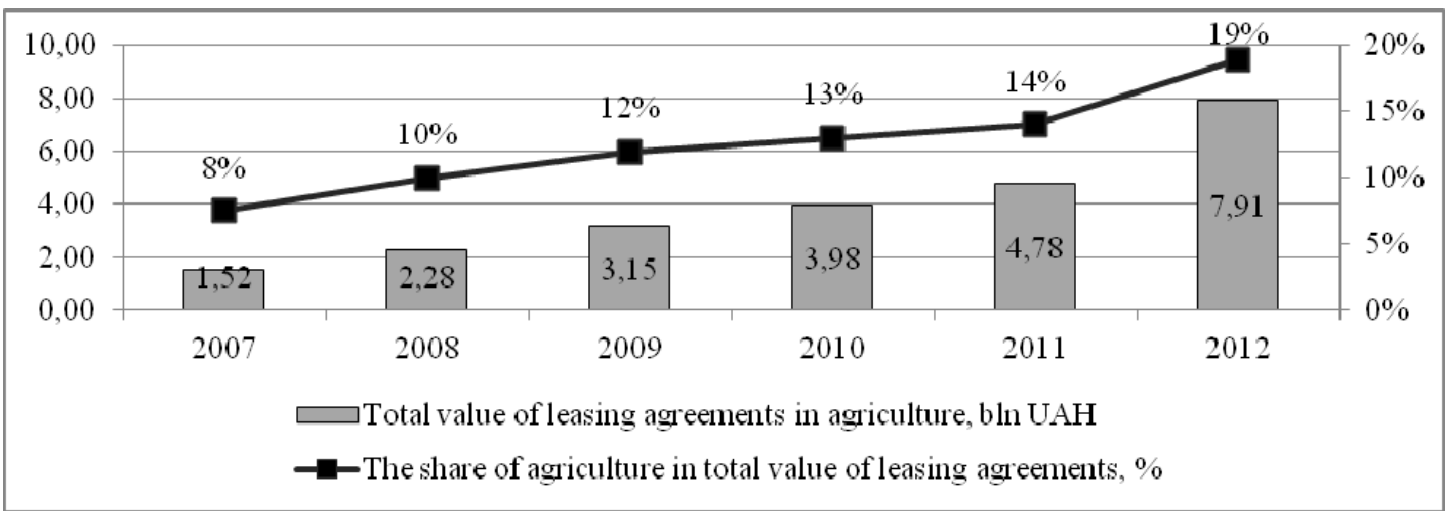

Source: State Commission for Regulation of Financial Services Markets of Ukraine

There are two state-owned leasing companies specialized in the agricultural sector UkrAgroLeasing (was created in 1998) and SpetsAgroLeasing (was created in 2010). UkrAgroLeasing leases domestically produced machinery, as well as machinery made in Russia and Belarus.

Through UkrAgroLeasing and SpetsAgroLeasing is provided the state support for the leasing of agricultural machinery. This support means lower payments for lessees and lower initial coverage requirements. For 2011, SpetsAgroLeasing and UkrAgroLeasing received $25 \mathrm{UAH}$ million and $200 \mathrm{UAH}$ million, respectively (EFSE, 2012).

The financial intermediation in agriculture could be evaluated by criteria as efficient allocation of loan funds and interest rate on agricultural loans (Barry and other 2000).

Efficiency criteria in economics specify that an optimal allocation of capital is characterized by equal marginal productivity of capital for all users in all geographic areas. Under perfect financial intermediation, two agricultural businesses producing the same products in different regions but having similar operations and risk characteristics should have similar access to loan funds and similar interest rates (Barry et al. 2000). 
About the low efficiency of the allocation of loan funds in Ukraine, shows breakdown of loans to agriculture by region compared with gross agricultural output (see Figure 8). Figure shows that the regions that produce largest gross agricultural output are not always the leaders in obtaining loans. So, in 2011 Vinnytsia region produced the largest volume of gross agricultural output, but obtained less loans by $10 \%$ compared to the Khmelnytskyi region, which produced 36\% less gross agricultural output.

Figure 8: Bank loans to agriculture versus gross agricultural output in 2011, UAH million

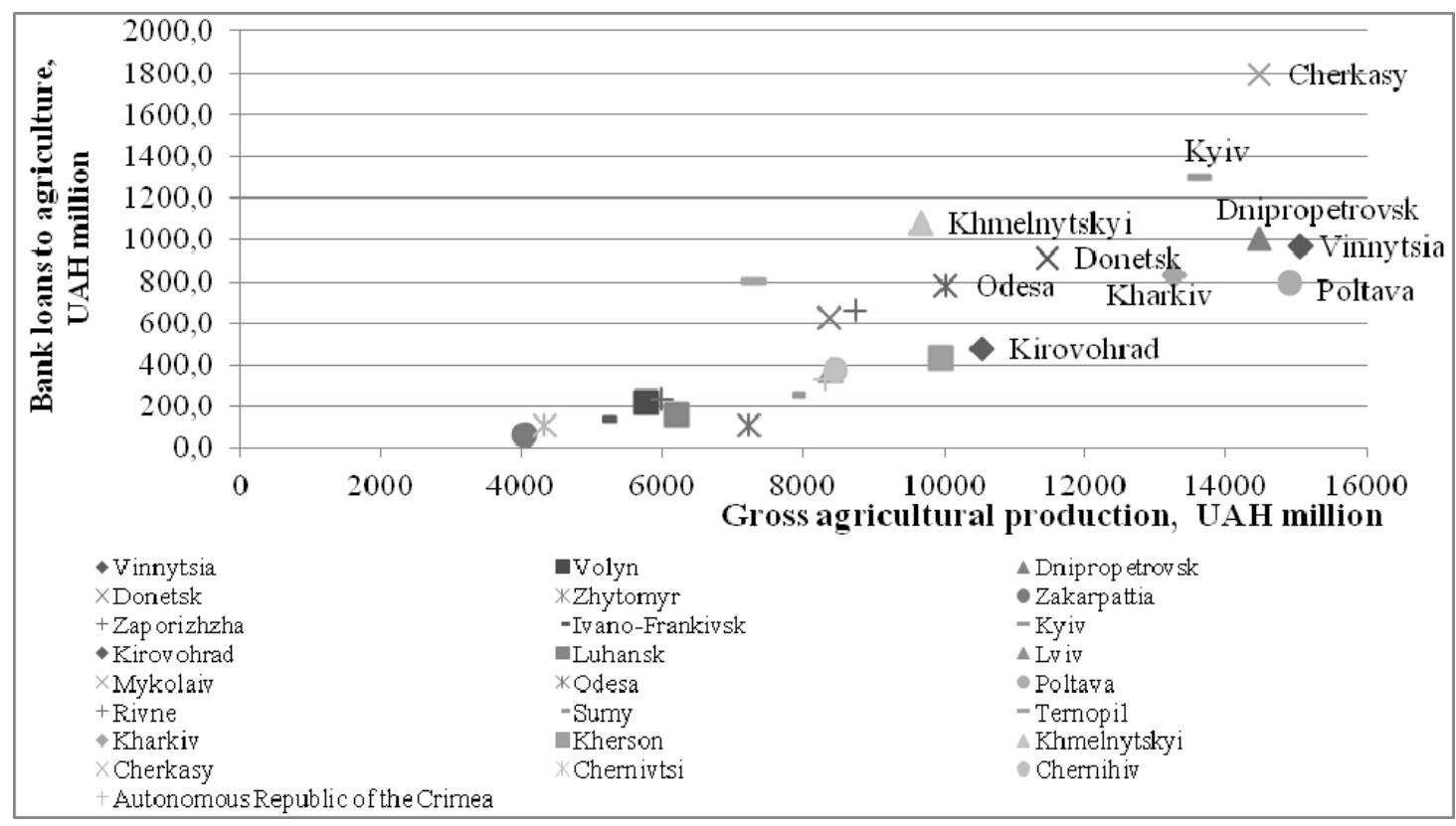

Source: SSSU (2012b), Ministry of Agriculture Policy and Food of Ukraine (2011)

About disparity in the distribution loan resources says so fact. Vinnytsia and Poltava regions can be considered as an area with similar natural and economic characteristics. Firstly, they have almost the same area of agricultural lands - about 1900 hectares. Secondly, they have almost the same number of farms - about 2400. They produce almost the same amount of gross agricultural production, but the amount of obtained loans varies greatly from year to year. In 2010, Poltava region obtained 4 times more loans than Vinnytsia region. In 2011, conversely, Vinnytsia region involved on $22 \%$ more loans than Poltava region. As well, they had not similar interest rates. In 2010-2011, the interest rates charged on agricultural loans by commercial banks in Vinnytsia region was higher on 3-4\% compare with Poltava region.

Odessa and Dnipropetrovsk regions are also with similar natural resources. These areas are the same size of agricultural land - about 2200 hectares, similar yearly average number of employees - about 37000 . However, they have a different number of farms: in the Odessa region, there are 6731 enterprises, in the Dnepropetrovsk 4014 (SSSU, 2012b), indicating a greater fragmentation of agricultural production in the Odessa area with a large number of small and medium enterprises. Nevertheless, 
the level of financial penetration in these areas is not identical and varied significantly. The level of agricultural loans in Dnipropetrovsk region is much higher (more than $29 \%$ compared with Odessa region in 2011) and the same could be said for the gross agricultural output (more than 44\% compared with Odessa region in 2011). This can be explained by the Dnepropetrovsk region has $60 \%$ more financial institutions than the Odessa region, while Odessa and Dnipropetrovsk regions had similar interest rates in $2011(17 \%)$.

A comparison of interest rates charged on agricultural loans and on loans to nonfinancial corporations over time is shown in Figure 9.

Figure 9: Average interest rates for agriculture, compensated by the State and profitability level of agriculture, $\%$

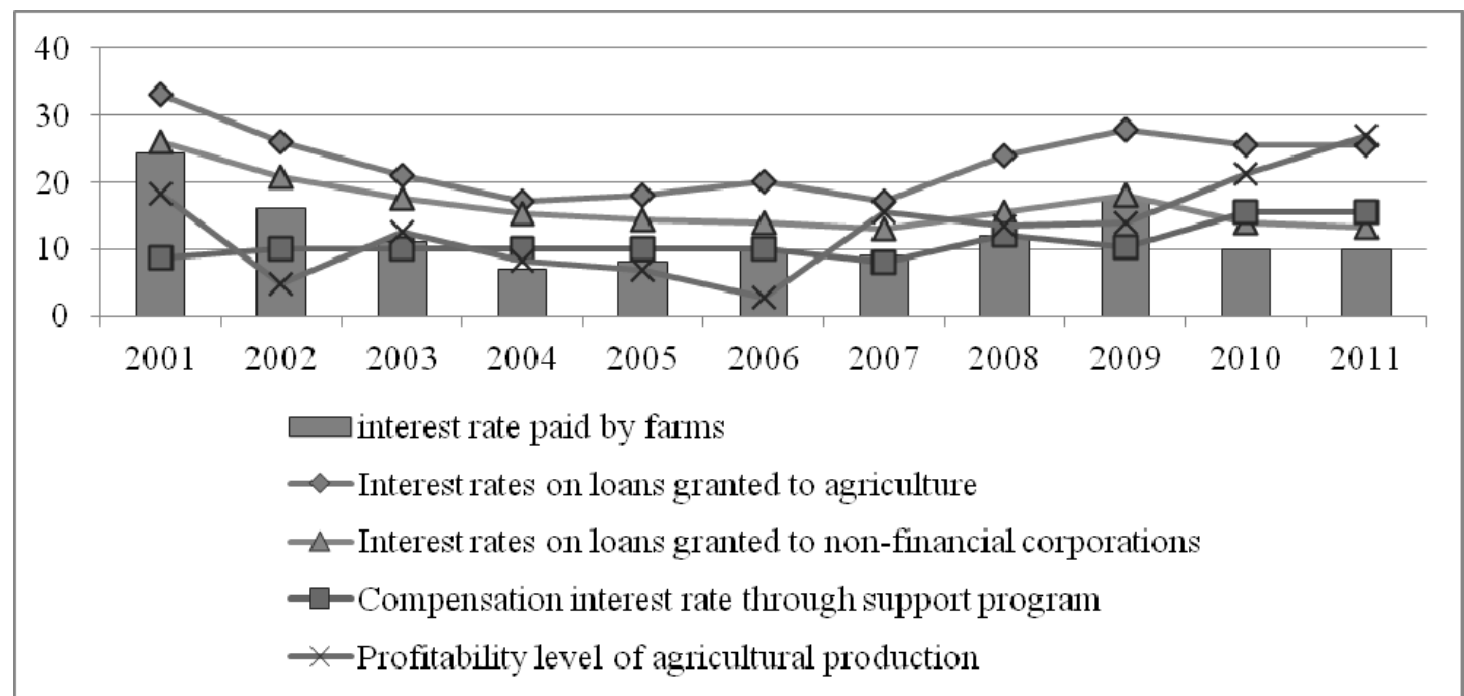

Source: Bulletin of the National Bank of Ukraine (2012), The Statistical Yearbook „Agriculture of Ukraine" for 2006-2011, Ministry of Agriculture Policy and Food of Ukraine (2001-2011)

Also included is compensation interest through support program and profitability level of agricultural production, serving as an indicator of efficiency of interest rate for agriculture. Several features are clearly evident. First, the interest rate on agricultural loans is higher over time than interest rate on loans to nonfinancial corporations. As mentioned above the banks cannot properly assess the agricultural risk because they understand insufficient the agricultural production and they increase their interest rates for farms. The second is the sharp increase in rate levels in 2008, which has been impacted by the recent financial crisis. The third is the high volatility of interest rate. The fourth is the interest rates on agricultural loans were much higher than the profitability level of agricultural production (exception only 2011). Even the compensation interest rate is not allowed to make profitable loans to agriculture in some years. The interest rate paid by farms was higher the profitability level of agricultural production mostly during 2001-2011 (see Figure 9). 
Dibrova, A. - Kukhar, O.

\section{Government support to agriculture in Ukraine}

Next step in describing the agricultural financial system for it is analysis of the ways in which farms meet their financial needs through budget system.

Agriculture via its strategic role (national food security) and their characteristics (seasonality, long production period, depending on natural factors, etc.) in all countries is under the special supervision of the state, which develops special government support to agriculture.

The government support to agriculture in Ukraine is realized through budgetary spending as well as budgetary revenue foregone (special tax regimes).

The budgetary revenue foregone on agriculture, coming from VAT exemptions, remains large compared to other sectors of the economy. The major types of VAT expenditures are granted to agriculture:

- VAT charged from sales of agricultural products remains on farm accounts to be used to purchase production inputs, and

- VAT charged from sales of meat and dairy products is not paid to the budget by processing plants, but returned to primary milk and meat agricultural producers.

The volume of government support to agriculture in Ukraine has increased by 3 times during 2001-2012. However, in 2009-2012 the volume declined, which was due to the influence of the global financial crisis that has negative affected the development of Ukraine (sharp inflation, rapid depreciation of the national currency, the decline in GDP, reduction of budget expenditures etc.).

Compare the government support to agriculture with GDP in agriculture indicated (Figure 10) positive tendency, except there is only 2009-2010, 2012, which was due to, as mentioned above, the influence of the global financial crisis. As can be seen from Figure 10, the share of government support in agricultural GDP increased from $2.8 \%$ in 2001 to $8.3 \%$ in 2012 , but it is more less than in USA - 27\%, EU - 45\%, Japan $63 \%$.

Figure 10: Agricultural budget support and GDP in agriculture in Ukraine

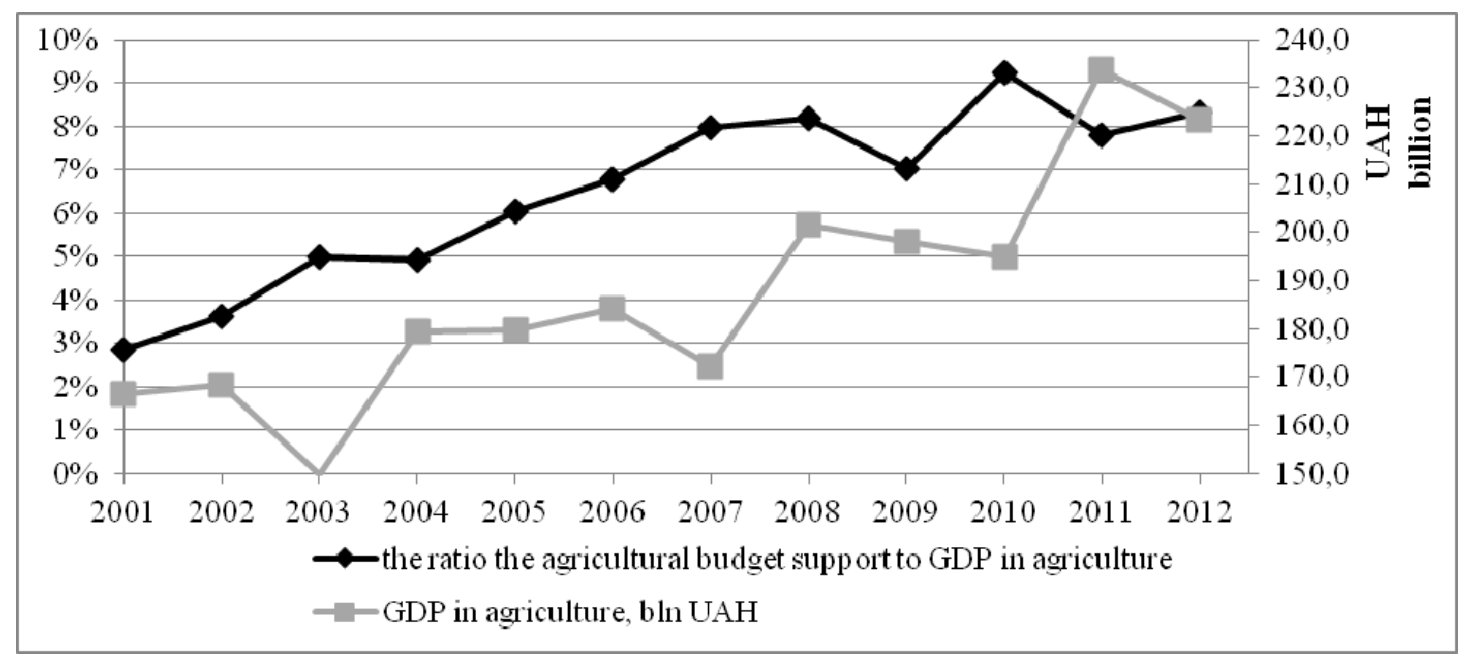

Source: SSSU (2013), Reports of the Accounting Chamber of Ukraine 
Previous study (Oliynyk 2012b) showed that for middle and low support countries with relatively low levels of government support and few protectionist measures, government involvement in agriculture has little effect on the agricultural labour productivity. For the high support countries such as Norway, Japan, Switzerland and Korea the government support significantly affects the agricultural labour productivity.

There were the budgetary spending dominated in the structure of government support during 2000-2008, but since 2009, the budgetary revenue foregone has begun to prevail that it was caused by the influence of the global financial crisis. As a result of special tax regimes could substantially increase financial support of agriculture, which is practically impossible to provide directly in budget (Kvasha and Oliynyk 2011; Oliynyk 2011b; Oliynyk 2012a).

Different indicators can be used to evaluate and compare the developments in government transfers and the distributional effects from agricultural policies (El Benni et al. 2012). The Organisation for Economic Co-operation and Development (OECD) uses indicators of agricultural support, which are comparable over time and between countries. Among the most popular is Producer Support Estimate (PSE), which measures the annual monetary value of gross transfers from consumers and taxpayers to agricultural producers, measured at the farm-gate level, arising from policy measures that support agriculture, regardless of their nature, objectives or impacts on farm production or income. PSE values are calculated by adding to the market price support the value of transfers to producers from other policies (OECD 2011a).

The publication of internationally comparable PSE figures has increased transparency on the nature and incidence of agricultural policies in OECD countries. In addition to the OECD countries, the PSEs have been also calculated for some emerging economies such as Brazil, China, Russia, Ukraine and South Africa.

The PSE concept has also contributed to establishing a base for internationally binding commitments on domestic support measures through the Aggregate Measure of Support (AMS) in the Uruguay Round of trade negotiations of the World Trade Organization (WTO). The summary measure, the relative PSE or \%PSE (expressed as a percentage of the gross support transfers to farmers in the value of the farmers' gross receipts), is frequently cited in the international debate on agricultural policies, and used as a yardstick of policy "misconduct", i.e., unfair competition with farmers in unsubsidizing countries (Blandford et al. 2008).

The percentage PSE (\%PSE) is often used for international comparisons. A \%PSE of $20 \%$ means that $20 \%$ of gross farm receipts come from transfers due to policy measures supporting producers. A \% PSE of $0 \%$ indicates that the estimated aggregate value of transfers to producers from consumers and taxpayers is zero. A \%PSE cannot be higher than $100 \%$, at which level all farm receipts come from policy measures, with no returns from the market (OECD 2011a).

Figure 11 compares the \%PSE between the EU and Ukraine over time. Three main features are clearly evident. First, the government transfers to farms in Ukraine have on average been relatively lower than the government transfers from consumers and taxpayers than for the EU's farms. Second, there has been convergence in the \%PSE as the government support to agriculture in the EU has declined, particularly since the EU enlargement from $33 \%$ in 2004 to $19 \%$ in 2012 . Finally, the higher volatility in the $\%$ 
PSE in Ukraine over time implies unsystematic government supports to agriculture with a lack of stability of agricultural policy in Ukraine. A substantial volatility in government support to agriculture in Ukraine in comparison with the EU in the case of Ukraine confirmed that the existence of budgetary spending and its growth cannot guarantee stability in government assistance to agriculture, if there are some other ad hoc policy measures.

Figure 11: Percentage PSE in Ukraine and EU countries (\%PSE)

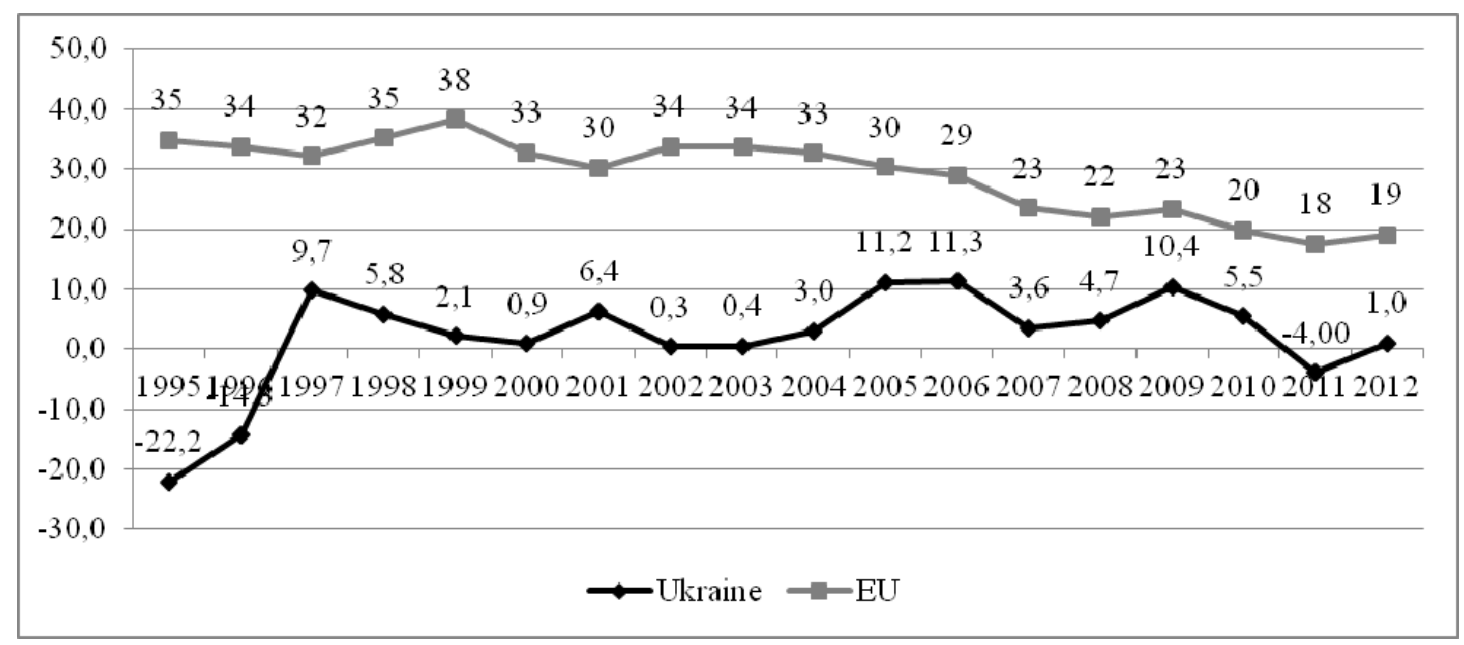

Source: OECD, http://stats.oecd.org/Index.aspx?DataSetCode=MON20113_1

Figure 12 presents the composition of the PSE in Ukraine between 2000 and 2012.

Figure 12: The structure of the PSE in Ukraine during the years 2000-2012

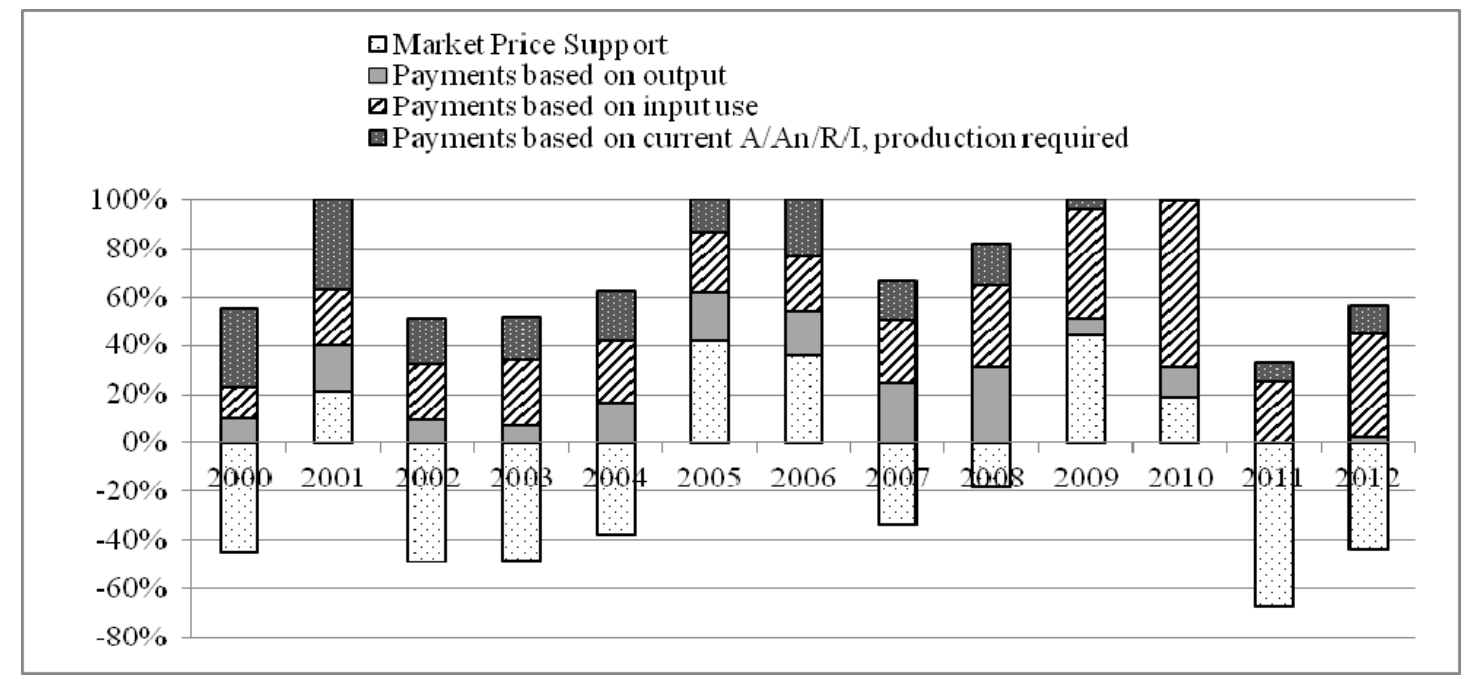

Source: OECD, http://stats.oecd.org/Index.aspx?DataSetCode=MON20113_1

According to this data payments based on output (mainly for livestock products) and input subsidies were Ukraine's principal instruments of government support to agriculture, especially during the years 2007-2010, where they accounted for a slightly 
more than $70 \%$ of the Ukrainian PSE. The bulk of this support is based on budgetary revenue foregone as opposed to actual budgetary spending. This is implemented through specific procedures to use the Value Added Tax (VAT) due from agricultural producers and processors as mentioned above.

Market price support has also significantly affected the total amount of support in the Ukrainian PSE. Moreover, only this component has experienced negative values owing from lower domestic prices than global or international market prices as the negative impact on the PSE. Except for the 2001, 2005-2006 and 2009-2010, the Ukrainian domestic agricultural prices were lower than global or international market prices of similar products. However, the level of PSE, which adjusts market price support in the total amount of subsidies to farmers, shows that government was able to reduce the negative impact of gap of domestic and world prices by providing budget financing: taxation of producers occurred only in 2011, when most products negative market price support is not offset by quite insignificant direct payments from the budget. For comparison, in most other OECD countries market price support has often been of a positive value and in the past, before the most recent CAP reforms, amounted between 44 and $60 \%$ of total PSE, but has declined during the most recent years substantially with a shift from market price support to direct budgetary support to agriculture and payments for rural development. The most recent developments in OECD countries have been adjustments of domestic agricultural prices closer to global or international market prices.

Due to the composition of PSE "Payments based on output" and "Payments based on input use" take significant share besides market price support (see Figure 12). Previously important output payments were substantially decreased due to budget constraints last years. Critical allocation were done in 2011; they were slightly increased in 2012, but amounted to $15 \%$ of their level in 2008. Another reason for the reduction in output payments is that in addition to actual budgetary outlays, some part of these payments is based on the budgetary revenue foregone. Thereby, meat and milk processors "re-direct" VAT due on processed products to their primary suppliers instead of transferring this tax to state budget. With Ukraine's WTO accession, concerns emerged about the impact of this subsidy on the country's AMS commitment. The previous mechanism was changed several times between 2010 and 2012, which meant that it functioned with interruptions and uncertainty. According to the latest agreed procedure to be in place until 1 January 2015, dairy and meet processors transfer their VAT in proportions fixed foe each year to the state budget and to a special account they open. The part transferred to the state budget will be directed to new animal payments for household producers, while the part transferred to the processors' special accounts will continue to be used for top-ups to producers delivering milk and meat (OECD, 2013).

The share of inputs payments was significant particularly last years. The largest component, accounting for $86 \%$ of all inputs support in 2010-12 and the largest single payments in the Ukrainian PSE, is based on so-called VAT accumulation mechanism. Agricultural producers can accumulate the VAT due on their primary and processed products on a special account. Accumulated funds should be directed to cover the VAT on purchased inputs, while the residual sum can be used for any other production 
Dibrova, A. - Kukhar, O.

purposes. Following rises in agricultural prices VAT-based transfers have been steadily increasing in 2010-12: from UAH 9.2 billion in 2009 to UAH 15.4 billion in 2012.

Other the OECD indicators of agricultural support are indicators of support estimate to consumers, indicators of support estimate to general services for agriculture, and indicators of total support estimate to agriculture (OECD, 2011a, 2011b).

CSE is the annual monetary value of gross transfers from (to) consumers of agricultural commodities, measured at the farm gate level, arising from policy measures that support agriculture, regardless of their nature, objectives or impacts on consumption of farm products. The percentage CSE $(\% \mathrm{CSE})$ is a share of consumption expenditure on agricultural commodities (at farm gate prices), net of taxpayer transfers to consumers (OECD, 2011a).

Figure 13 presents the structure of the CSE in Ukraine for the 2000-2012. During the 2001, 2005-2006, and 2008-2010, the CSE was characterized by the provision of support to producers just through the transfers from consumers. On the other hand, the 2000, 2002-2004, 2007, 2011-2012, Ukrainian consumers received subsidies from agricultural policy transfers. Such a situation has contributed to more rapid farm restructuring as one of the reasons for the decline of Ukrainian farmers. Some farmers due to lower profitability in farming have exited from farming activities or have migrated from rural areas to urban areas or have migrated abroad.

Figure 13: The CSE structure in Ukraine during 2000-2012

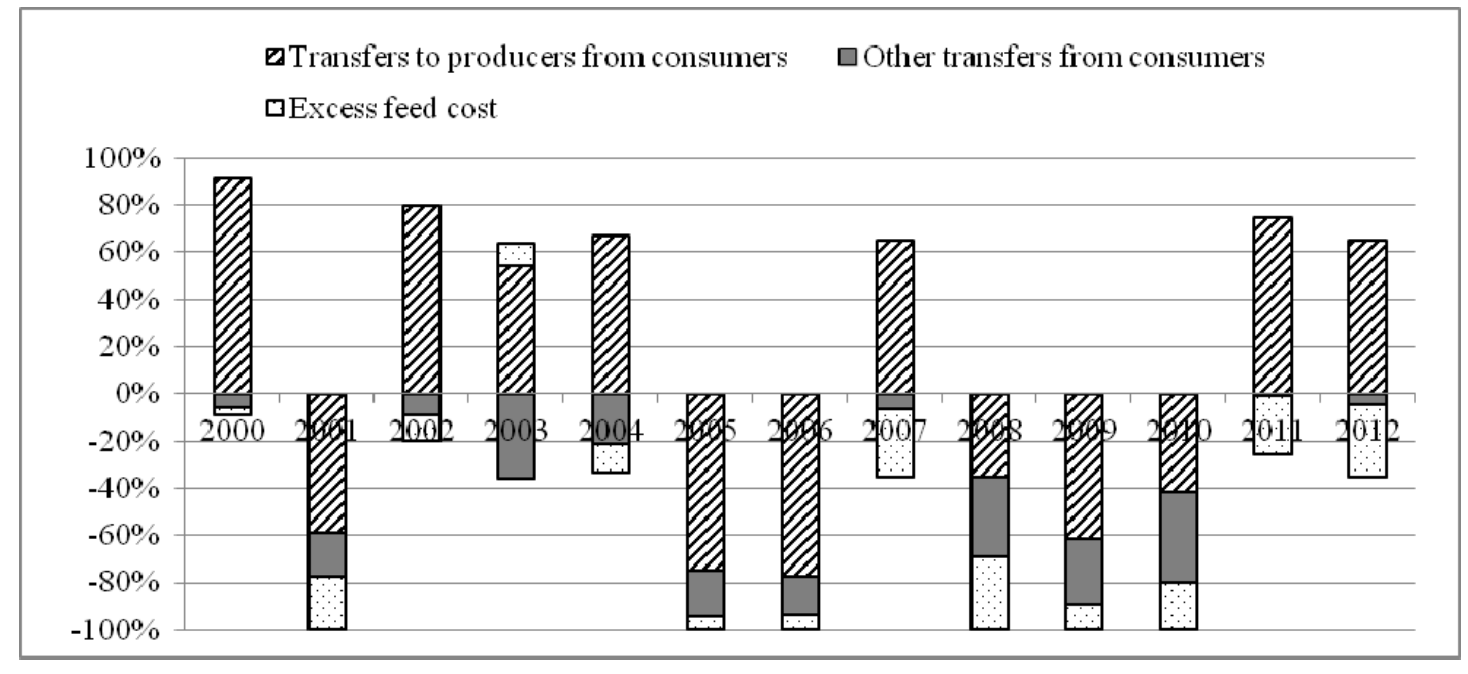

Source: OECD, http://stats.oecd.org/Index.aspx?DataSetCode=MON20113_1

The GSSE transfers capture payments to eligible private or public services provided to agriculture generally. Unlike the PSE and CSE transfers, the GSSE transfers are not destined to individual producers or consumers, and do not directly affect farm receipts (revenue) or consumption expenditure, although they may affect production or consumption of agricultural commodities in the longer term (OECD, 2011a).

The composition of the GSSE transfers in Ukraine is presented in Figure 14.

As can be seen from Figure 14, the share of budgetary payments for financing research and development activities and thus improving agricultural production has 
been reduced from $20 \%$ to $9 \%$ during the $2000-2012$ period. The share of the GSSE budgetary payments for financing agricultural training and education in Ukraine has taken a significant greater part in Ukraine in comparison with the EU member states. For example, the share of the budgetary payments to agricultural schools in Ukraine was between 21 and 36\% during the 2000-2012 period, while in the EU member states only around $0.4 \%$.

The share of the budgetary payments for infrastructure and marketing in the EU member states was very high: between 33 and $70 \%$ for infrastructure and between 4 and $12 \%$ for marketing. While in Ukraine, these components were only between 16 and $40 \%$ and between 1 and $2 \%$, respectively. Relatively low budgetary payments for financing of improvement of off-farm infrastructure and relatively low budgetary payments for financing of assistance to marketing and promotion of agro-food products lead to increased production and transportation costs and mitigate competitiveness of Ukrainian agro-food products on domestic and international markets. One of the reasons for less favourable values of market price support can be also insufficient funding and investments in infrastructure, marketing and promotion of Ukrainian agro-food products.

Figure 14: The GSSE structure in Ukraine during the 2000-2010

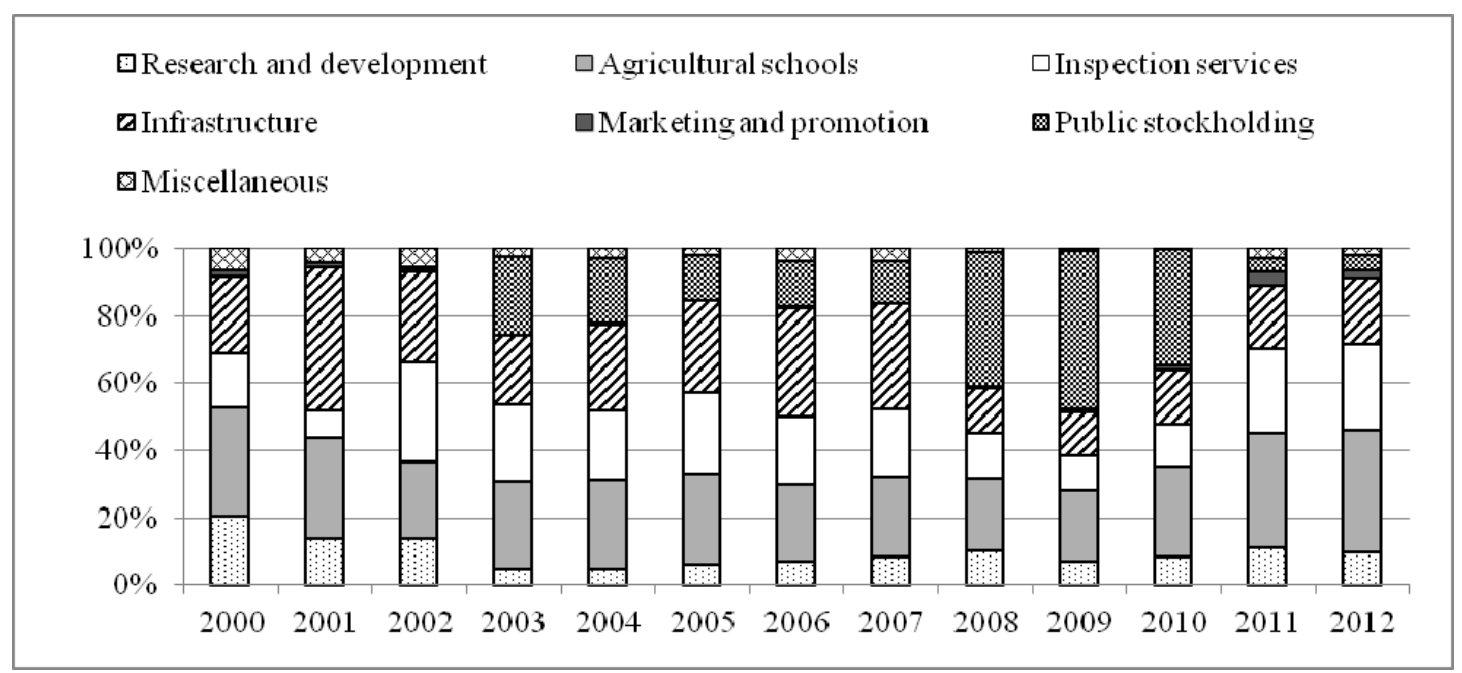

Source: OECD, http://stats.oecd.org/Index.aspx?DataSetCode=MON20113_1

TSE is the annual monetary value of all gross transfers from taxpayers and consumers arising from policies that support agriculture, net of the associated budgetary receipts, regardless of their objectives and impacts on farm production and income, or consumption of farm products (OECD, 2011a, 2011b). The percentage TSE (\%TSE) is calculated as a share of agricultural GDP. During 2000-2012, Ukraine has experienced rather unsystematic agricultural policy measures, which have caused significant cyclical fluctuations in the \%TSE indicator (Figure 15).

As shown in Figure 15, the \%TSE for Ukraine tends to increase with substantial cyclical oscillations. On the other hand, the \%TSE tends to decline a slightly with rather stable developments between the individual years. Therefore, different are patterns and the significant fluctuations in the TSE (\%) development in Ukraine 
compared to more stable, but declining tendency in the EU member states. Therefore, this support for agriculture of Ukraine differs significantly from the most recent developments in the EU member states. In Ukraine, the \% TSE is characterized by a lack of stability and a steady upward trend.

Figure 15: The percentage TSE (\%TSE) in Ukraine and in the EU member states

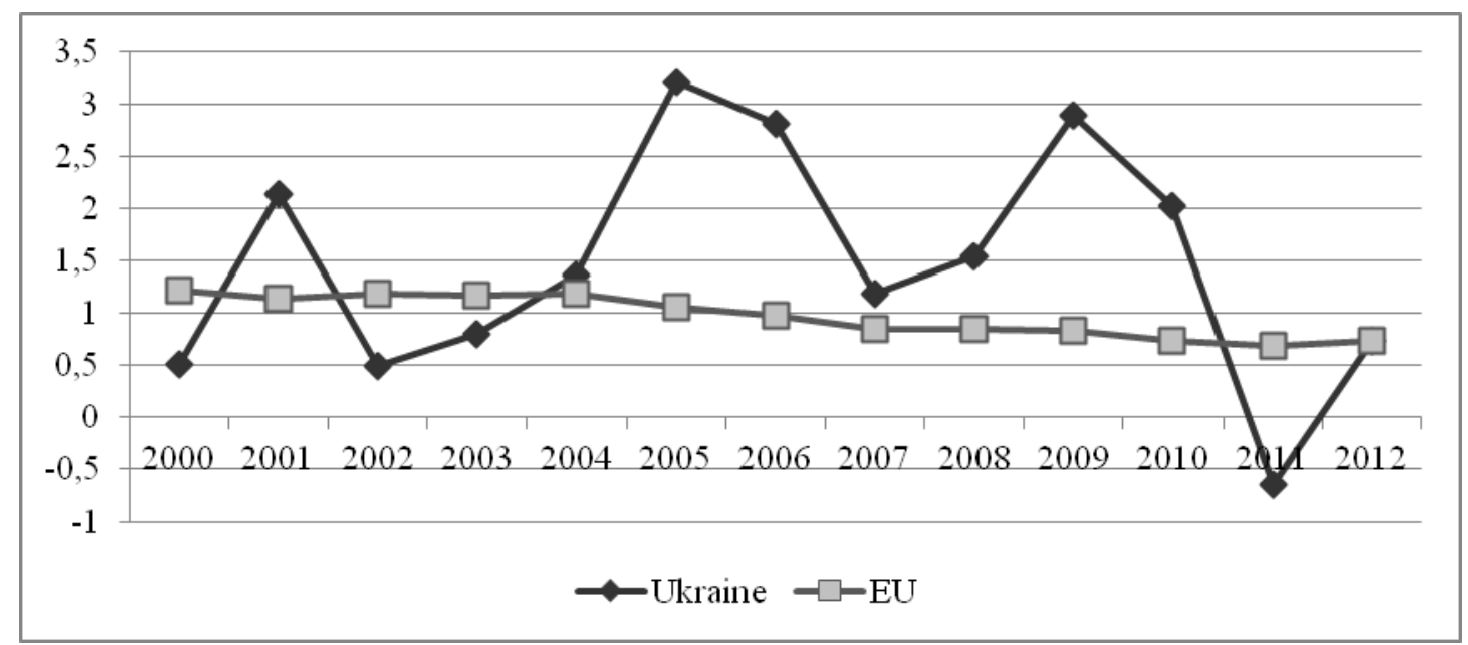

Source: OECD, http://stats.oecd.org/Index.aspx?DataSetCode=MON20113_1

The main strategic objective of Ukraine should be development and implementation of long-term strategy of agricultural and rural development that would allow carrying out a transparent agricultural policy focusing on a greater stability and sustainability in competitive agricultural and rural development.

\section{Conclusion}

Ukraine's farm sector is characterized by a three-way split between tiny household farms, medium-sized private farms and large corporate farms.

Rural households (family farms) have important role in agriculture in Ukraine. Their percentage indicates substantial importance in Ukrainian agricultural land use structures $-38.1 \%$ in 2012. Although the share of rural households in agricultural output decreased by $19.2 \%$, it remains significant and consists $49.3 \%$ in 2012 .

The second major player in agriculture are the corporate farms (private agricultural entities), their share in total agricultural land use was 36.9\% in 2012 and their percentages in agricultural output increased by $49.7 \%$ in 2012 . It was caused the emergence and development of large agricultural enterprises.

The average size of agricultural enterprises has increased significantly last 7 years. The percentage of agricultural enterprises greater than 10000 ha of agricultural land use has increased from 3.3\% in 2006 to $15.3 \%$ in 2012 .

The percentage of employment in agriculture in the Ukrainian economy decreased from $17.5 \%$ in 2006 to $17.2 \%$ in 2012 , on the other hand, the share of value added of agriculture, forestry and hunting in the gross domestic product increased from $8.6 \%$ to $9.2 \%$ during the same time. 
The assessment of agricultural financial system implies the analyses of the ways in which farms meet their financial needs through the financial sector, directly with other economic agents and through the budgetary system.

The commercial banks are the main financial intermediaries for agriculture in Ukraine. But the banks are reluctant to lend to farms because they cannot properly assess the risks through insufficient understanding of agricultural production. The banks are lending mostly larger vertically integrated large agricultural enterprises. Smaller farms and rural households are underrepresented in bank portfolios. The value of loans at constant prices increased by 46 times over the past 11 years and it was 31.9 billion UAH in 2012. The interest subsidy scheme, which has been implemented since 2000, played important role in agricultural lending. During 2005-2008, the share of preferential loans in total loans was over $50 \%$. But the interest subsidy program has a number of weaknesses, which requires a review of the state support to agriculture.

Other financial institutions such as credit unions, leasing companies, insurance companies and other financial markets play marginal role in funding of farms in Ukraine.

The efficiency of financial intermediation in agriculture is low in Ukraine. Based on criteria "efficient allocation of loan funds" has been shown that regions of Ukraine with similar natural and economic characteristics have different access to loan funds and different interest rates. Interest rate on agricultural loans is high, and higher than the average in Ukraine, it has significant volatility. The level of agriculture profitability does not cover the level of interest rate.

The volume of government support to agriculture in Ukraine has increased significantly by 3 times during 2001-2012. However in 2009-2012 the volume declined, which was due to the influence of the global financial crisis that has negative affected the development of Ukraine (sharp inflation, rapid depreciation of the national currency, the decline in GDP, reduction of budget expenditures etc.).

Analysis of the producer support estimate in Ukraine showed that an unsuccessful price regulation caused the decrease to zero the producer support in 2000, 2002-2003, 2011.

The higher volatility in the \% PSE in Ukraine over time implies unsystematic government supports to agriculture with a lack of stability of agricultural policy in Ukraine. A substantial volatility in government support to agriculture in Ukraine in comparison with the EU in the case of Ukraine confirmed that the existence of budgetary spending and its growth cannot guarantee stability in government assistance to agriculture, if there are some other ad hoc policy measures.

The main strategic objective of Ukraine should be development and implementation of long-term strategy of agricultural and rural development that would allow carrying out a transparent agricultural policy focusing on a greater stability and sustainability in competitive agricultural and rural development. 


\section{References}

1. Allen, F. and Gale, D. (2001): Comparing financial systems: a survey. Philadelphia: University of Pennsylvania Wharton School.

2. Bain, A. (1996): The Economics of the Financial System. Cambridge MA: Blackwell, 2nd ed.

3. Balmann, A., Kataria, K., Schaft, F. and Kulyk, I. (2013): Efficiency and productivity of Ukrainian Agroholdings, Paper presented at the 2013 IATRC Symposium, Productivity and Its Impacts on Global Trade, Factor Markets session, June 2-4, 2013, Seville, Spain.

4. Barry, P., Ellinger, P., Hopkin, J. and Baker, C. (2000): Financial management in agriculture, 6th Edition, The Interstate Printers and Publishers, Inc., Danville, IL, USA.

5. Blandford, D., Brunstad R., Gaassland I. and Vardal, E. (2008): Optimal agricultural policy and PSE measurement: an assessment and application to Norway. The 82nd Annual Conference of the Agricultural Economics Society Royal Agricultural College 31st March to 2nd April 2008.

6. Bodie, Z. and Merton, R. (2000): Finance. Upper Saddle River, New Jersey: Prentice Hall.

7. Bojnec, S.., Kvasha, S. and Oliynyk, O. (2013): Comparative evaluation of financing small and medium farms in Ukraine and Slovenia. EARTH Bioresources and Life Quality, 2(1), No. 3: 1-13. http://gchera-ejournal.nubip.edu.ua/index.php/ebq1/article/view/103.

8. Buckle, M. and Thompson, J. (1998): The UK financial system. Theory and practice. Manchester University Press, 3rd ed.

9. EBRD-World Bank (2009). BEEPS 2009.

Website: http://beeps.prognoz.com/beeps/Home.ashx.

10. EFSE (2012): Potential for agricultural finance in Ukraine: Study paper. EFSE. website: http://www.efse.lu/media/pdfs/studies/other_sector_studies/potential-of-agriculturalfinance-in-ukraine_efse-df_2012_eng.pdf.

11. El Benni N., Finger R., Mann S., Lehmann B. (2012): The distributional effects of agricultural policy reforms in Switzerland. Agricultural Economics - Czech, 58 (11), pp. 497-509.

12. Global Ag Investments, LLC (2013): Ukraine Agriculture and Investment Opportunities: Why Ukraine? Available at the website: http://www.globalaginvestments.com/Ukraine\%20Agriculture\%20and\%20Investment $\% 20$ Opportunities.htm.

13. Hartmann, P., Maddaloni, A. and Manganelli, S. (2003): The Euro Area Financial System: Structure, Integration and Policy Initiatives. Working paper No. 230. Frankfurt: European Central Bank.

14. Kvasha, S. and Oliynyk, O. (2011): The analysis of budget support efficiency of agriculture in Ukraine. Conference proceeding: Economics of agriculture and environmental sciences in the context of globalization and regional challenges - Kyiv, Ukraine.

15. Mykhayliv, D. and Zauner, K.G. (2013a): Investment behaviour, corporate control, and private benefits of control: evidence from a survey of Ukrainian firms. Bulletin of Economic Research. DOI: 10.1111/boer.12001.

16. Mykhayliv, D. and Zauner, K.G. (2013b): Investment behavior and ownership structures in Ukraine: Soft budget constraints, government ownership and private benefits of control. Journal of Comparative Economics, 41(1), pp. 265-278.

17. National Bank of Ukraine (2012): Bulletin of the National Bank of Ukraine. Kyiv.

18. National Bank of Ukraine (2013): Bulletin of the National Bank of Ukraine. Kyiv.

19. OECD (2011): OECD's producer support estimate and related indicators of agricultural support. Concepts, Calculations, Interpretation and Use (The PSE Manual). Paris: OECD. 
20. OECD (2012a): Competitiveness and Private Sector Development: Ukraine 2011 Sector Competitiveness Strategy. Paris: OECD.

21. OECD (2012b): Implementing Credit Guarantee Schemes in Ukraine: The Case of Agribusiness, Private Sector Development, Policy Handbook. Paris: OECD.

22. Oliynyk, O. (2011a): The impact of agroholding activity on rural areas development in Ukraine. Conference proceeding: Development prospects of rural areas lagging behind in the CEE region - Gödöllö, Hungary.

23. Oliynyk, O. (2011b): Agricultural taxation in Ukraine: challenges and perspectives. Economics and Organization of Food Economy. No. 94, pp. 39-48.

24. Oliynyk, O. (2012a): The estimate of support to agriculture in Ukraine using OECD indicators. Folia Pomeranae Universitatis Technologiae. Oeconomica. No. 69, pp. 59-69.

25. Oliynyk, O. (2012b): As international comparison of the effect of government support on agricultural productivity. Annual of Agricultural Economics and Rural Development, 99(3), pp. 70-76.

26. Oliynyk, O, and Oliinyk, L. (2013): Evaluating financial intermediation for agriculture in Ukraine. - Conference proceeding: Business Management- Practice and Theory in the 21st Century - Nitra, Slovak Republic.

27. Schmidt, R. and Hryckiewicz, A. (2006): Financial Systems - Importance, Differences and Convergence. Institute for Monetary and Financial Stabillity. Working Paper Series No. 4.

28. Schmidt, R. and Tyrell, M. (2003): What constitutes a financial system in general and the German financial system in particular? Working Paper Series No.111. Finance \& Accounting.

29. Schmidt, R., Hackethal, A. and Tyrell, M. (2001): The Convergence of Financial Systems in Europe. Working Paper Series No. 75. Finance \& Accounting.

30. SSSU (2007): Statistical Yearbook of 2006 "Agriculture of Ukraine". Kyiv: State Statistics Service of Ukraine.

31. SSSU (2012a): Main Agricultural Characteristics of Households in Rural Areas in 2011. Kyiv: State Statistics Service of Ukraine.

32. SSSU (2012b): Statistical Yearbook of 2011 "Agriculture of Ukraine". Kyiv: State Statistics Service of Ukraine.

33. SSSU (2012c):The Statistical Yearbook of Ukraine for 2011. Kyiv: State Statistics Service of Ukraine.

34. SSSU (2013): Statistical Yearbook of 2012 "Agriculture of Ukraine”. Kyiv: State Statistics Service of Ukraine.

35. von Cramon-Taubadel, S., Nivyevskiy, O., Elsner von der Malsburg, E. and Movchan, V. (2007): Distortions to Agricultural Incentives in Ukraine, Agricultural Distortions Working Paper 06. Washington, DC: The World Bank. Available at: http://siteresources.worldbank.org/INTTRADERESEARCH/Resources/5448241146153362267/Ukraine_0807.pdf.

36. von Cramon-Taubadel, S., Zorya, S. and Striewe, L. (eds.) (2001): Policies and Agricultural Development in Ukraine. Göttingen and Kyiv. Available at: http://www.policy.hu/kobzev/Agrarbook_2001.pdf.

37. Zinych, N. and Odening, M. (2009): Capital market imperfections in economic transition: empirical evidence from Ukrainian agriculture. Agricultural Economics, 40(6), pp. 677689. 